\title{
PERBEDAAN KEPUASAN HIDUP PADA LAKI-LAKI DAN PEREMPUAN DENGAN HIVIAIDS
}

\author{
Edward Septianto Gani ${ }^{1}$, Ediasri Toto Atmodiwirjo² ${ }^{2}$ dan Naomi Sutikno ${ }^{3}$ \\ ${ }^{1}$ Prodi Magister Psikologi Profesi, Universitas Tarumanagara, Jakarta \\ Email: edward.717172009@stu.untar.ac.id \\ ${ }^{2}$ Fakultas Psikologi, Universitas Tarumanagara, Jakarta \\ Email:ediasria@fpsi.untar.ac.id \\ ${ }^{3}$ Fakultas Psikologi Universitas Tarumanagra, Jakarta \\ Email:naomis@fpsi.untar.ac.id
}

Masuk : 16-04-2019, revisi: 16-04-2020, diterima untuk diterbitkan : 23-04-2020

\begin{abstract}
Human Immunodeficiency Virus (HIV) is an autoimmune disease that has not yet to be cured. HIV affects many aspects of the lives of sufferers, including psychological aspects. The population of people with HIV has a significant increase every year. People with HIV will experience physical and psychological problems that will affect their life satisfaction. Life satisfaction is one way that can be used to see whether someone is satisfied with aspects that are considered important in his life. There are differences in research results regarding life satisfaction in terms of gender. This study aims to look further, whether there are differences in life satisfaction in men and women with HIV-Aids. Participants in this study numbered 66 people in one of the HIV communities in Jakarta. Be found 30 male participants and 36 female participants. This research uses quantitative research methods. Data collection uses a life satisfaction questionnaire that has been adapted in Indonesian language. Data was analyzed by independent sample t-test. The results of this study indicate that there is no significant difference in life satisfaction between male and female. These results indicated that there are other factors such as support systems that increase the satisfaction of PLHIV, but not gender.
\end{abstract}

Keywords: HIV, Life satisfaction, gender

\begin{abstract}
ABSTRAK
Human Immunodeficiency Virus (HIV) adalah penyakit autoimun yang sampai saat ini belum dapat disembuhkan. HIV berdampak pada banyak aspek kehidupan penderitanya, termasuk aspek psikologis. Populasi orang dengan HIV (odha) setiap tahun mengalami peningkatan yang signifikan. Individu dengan HIV akan mengalami permasalahan-pemasalahan secara fisik dan psikologis yang akan memengaruhi penilaian terhadap kepuasan hidupnya. Kepuasan hidup merupakan salah satu tolak ukur yang bisa digunakan untuk melihat apakah seseorang merasa puas dengan aspek-aspek yang dinilai penting dalam hidupnya. Terdapat perbedaan hasil penelitian mengenai kepuasan hidup ditinjau dari jenis kelamin. Penelitian ini bertujuan untuk mengkaji lebih lanjut, apakah terdapat perbedaan kepuasan hidup pada laki-laki dan perempuan dengan HIV-Aids. Partisipan dalam penelitian ini berjumlah 66 orang pada salah satu komunitas HIV di Jakarta. Dengan jumlah partisipan odha laki-laki sebanyak 30 orang dan odha perempuan sebanyak 36 orang. Penelitian ini menggunakan metode penelitian kuantitatif. Pengumpulan data menggunakan kuesioner kepuasan hidup yang telah diadaptasi dalam bahasa Indonesia. Analisis data yang digunakan pada penelitian ini dengan menggunakan independent sample t-test. Hasil dari penelitian ini menunjukkan bahwa tidak ada perbedaan yang signifikan kepuasan hidup antara odha laki-laki dengan odha perempuan. Hasil ini dapat menunjukkan adanya faktor lain seperti support system yang mempengaruhi kepuasan hidup odha, bukan sekedar faktor jenis kelamin.
\end{abstract}

Kata kunci: HIV, kepuasan hidup, jenis kelamin

\section{PENDAHULUAN}

\section{Latar Belakang}

Human Immunodeficiency Virus (HIV) merupakan virus yang menyerang sel darah putih yang menyebabkan menurunnya system kekebalan tubuh seseorang yang berdampak pada fungsi sel darah putih untuk melawan infeksi, virus, dan penyakit. Penularan HIV dapat melalui beberapa cara, yaitu dengan hubungan seksual yang beresiko, penggunaan jarum suntik atau peralatan lain yang sudah terkontaminasi virus HIV, transfusi darah, dan dapat juga ditularkan melalui ibu kepada 
anaknya ketika masa kehamilan, dan menyusui. Virus HIV yang menyerang system kekebalan tubuh seseorang dalam jangka waktu lima sampai dengan sepuluh tahun akan berkembang menjadi Acquired Immune Deficiency Syndrome (AIDS). Permasalahan HIV/AIDS telah ditetapkan sebagai masalah kesehatan utama di dunia (WHO, 2017).

World Health Organization (WHO) mencatat penderita HIV mencapai 35 juta jiwa pada tahun 2017 dan sekitar 940.000 jiwa meninggal karena virus HIV. Penderita HIV di Indonesia sendiri sampai dengan Desember 2017 dilaporkan sebanyak 14.640 orang, dengan persentase tertinggi pada umur 25-49 tahun (69,2\%), diikuti kelompok umur 20-24 tahun (16,7\%), dan kelompok umur $>50$ tahun (7,6\%). Hasil perhitungan yang dilakukan oleh Kementrian Kesehatan Republik Indonesia (KKRI) dari tahun 2015-2017 menunjukkan persentase kematian HIV/AIDS yang meningkat sebesar 1\%.

Berdasarkan wawancara yang peneliti lakukan kepada salah seorang dokter di rumah sakit "X",bahwa penderita HIV/AIDS yang melakukan pengobatan paling banyak adalah istri yang terinfeksi dari suaminya. Biasanya mereka menyadari perlu melakukan tes HIV/AIDS ketika mereka mengetahui suami mereka positif terinfeksi HIV/AIDS atau suami mereka meninggal karena virus tersebut. Pada pria virus HIV tertular melalui hubungan heteroseksual, hubungan sejenis, dan melalui penggunaan jarum suntik yang telah terinfeksi virus HIV. Wawancara yang dilakukan peneliti dengan narasumber "Y" yang telah terinfeksi HIV/AIDS melalui suaminya selama 11 tahun. "Y" mengatakan bahwa di masa-masa awal infeksi oportunis menyebabkan banyak masalah yang muncul, selain semakin melemahnya kondisi fisik, perasaan malu dan perasaan tidak bisa menerima saat pertama kali positif HIV. Selain itu, adanya stigma masyarakat yang masih mengucilkan orang dengan HIV/AIDS (ODHA) membuat "Y" sempat berpikir untuk mengakhiri hidupnya. Pada tahun ke lima "Y" merasa jenuh harus meminum obat setiap harinya. "Y" pernah mencoba untuk putus obat tetapi hanya bertahan satu bulan karena kondisi tubuhnya memburuk dan membuatnya harus dirawat dirumah sakit. Pernyataan di atas diperkuat oleh Sarafino dan Smith (2010) yang menyatakan bahwa suatu penyakit yang bersifat parah dapat menimbulkan perasaan negatif seperti kecemasan, depresi, stress, ataupun rasa tidak berdaya dan perasaan-perasaan negatif lainnya.

HIV/AIDS memiliki dampak pada seluruh aspek kehidupan penderitanya berupa aspek fisik, aspek finansial, dan aspek sosial. Pada aspek fisik, kondisi fisik ODHA yang menurun seiring berkembangnya HIV menjadi AIDS serta efek samping dari pengobatan yang dilakukan (Siahaan, 2017; Katz et al., 2013; Schweitzer et al., 2010). Aspek selanjutnya adalah aspek finansial yang diakibatkan karena hilangnya pekerjaan ataupun besarnya biaya yang dikeluarkan untuk biaya perawatan atau check up rutin yang tidak ditanggung oleh pemerintah (Siahaan, 2017; Katz et al., 2013; Schweitzer et al., 2010).

ODHA akan mengalami kendala dalam mengembangkan keintiman dan kepercayaan dengan pasangan, terutama jika tidak adanya dukungan yang diberikan oleh keluarga. Permasalahan yang paling utama adalah masih terdapatnya stigma negatif dan diskriminasi dari masyarakat. Stigma tersebut berupa HIV adalah penyakit menular yang tidak dapat disembuhkan dan berujung pada kematian, sehingga tidak ingin menggunakan peralatan makan dan mandi yang sama dengan penderita HIV dan penderita HIV selalu dikaitkan dengan hal "negatif" karena berkaitan dengan pelanggaran norma dan moral sosial (Siahaan, 2017; Katz et al., 2013; Schweitzer et al., 2010).

Permasalahan-permasalahan baik secara internal maupun eksternal individu berdampak pada penilaian individu dengan segala aspek kehidupannya. Individu yang pertama kali didiagnosa terinfeksi HIV/AIDS akan merasakan emosi negatif seperti kesedihan, ketakutan, kecewa, marah, 
merasa bersalah, hilangnya kontrol diri, serta menganggap bahwa dirinya akan meninggal (Moskowitz, Wrubel, Hult, Maurer, \& Acree, 2013; Paputungan, 2013). Hasil wawancara dengan salah seorang dokter spesialis penyakit dalam mengatakan bahwa ODHA akan stres, merasa bahwa dirinya akan meninggal, bahkan akan muncul gejala penyakit psikologis seperti stres, depresi, dan psikosomatis.

Permasalahan di atas akan memengaruhi penilaian ODHA terhadap keseluruhan kehidupannya. Hal ini sesuai dengan penelitian yang dilakukan oleh Strine, Chapman, Balluz, Moriarty, \& Mokdad (2008) bahwa faktor-faktor yang berhubungan dengan kesehatan seperti penyakit kronis, kegelisahan, dan gangguan fungsi fisik berkorelasi positif dengan kepuasan hidup seseorang. Kepuasan hidup dan kesehatan memiliki hubungan dua arah, artinya jika seseorang memiliki kesehatan yang baik, maka akan mempengaruhi kualitas kepuasan hidupnya. Kondisi tersebut tentunya juga dipengaruhi oleh faktor-faktor pendukung lainnya (Strine, Chapman, Balluz, Moriarty, \& Mokdad, 2008).

Permasalahan yang dialami oleh ODHA tidak saja membutuhkan penanganan medis tentunya juga memerlukan penanganan psikologis. Individu yang mampu mengatur perasaan yang tidak menyenangkan dalam hidupnya dan mengubah sudut pandangnya dalam memaknai kehidupan akan memengaruhi kepuasan hidupnya. Kepuasan hidup sendiri merupakan kemampuan individu secara kognitif dalam menilai puas atau tidak hidup yang dijalani dan mengarah pada kebahagiaan dalam hidupnya. Penilaian ini termasuk pengalaman-pengalaman secara keseluruhan yang dialami dalam kehidupan individu (Diener, 2009).

Vicki, Rose Anne dan Francesca (2012) menyatakan bahwa infeksi HIV/AIDS menimbulkan dampak yang kompleks terhadap penderitanya selain menurunkan daya tahan tubuh dan infeksi oportunitis yang mengikutinya, masalah psikologi maupun sosial juga dialami oleh orang yang terdeteksi HIV/AIDS. Secara psikologis orang dengan HIV/AIDS dapat mengalami distress psikologi, termasuk harga diri yang rendah, kecemasan, ketakutan, dan bahkan berkurangnya rasa kepuasan terhadap hidupnya. Dari berbagai faktor ODHA rentan mengalami permasalahanpermasalahan yang dapat berdampak pada kesejahteraan subjektif mereka.

Individu dengan kepuasan hidup yang tinggi adalah individu yang memiliki tujuan dalam hidupnya dan berhasil untuk mencapai tujuan tersebut. Jadi, individu yang memiliki kepuasan hidup tinggi merasa bahwa hidup mereka bermakna dan memiliki tujuan dan nilai yang penting dalam kehidupan mereka (Diener, 2009). Selain itu, Diener (2009) mengatakan bahwa individu yang puas akan kehidupannya adalah individu yang menilai bahwa kehidupannya memang tidak sempurna dan segala sesuatu tidak selalu berjalan dengan baik, namun selalu mempunyai keinginan untuk berkembang dan menyukai tantangan.

Pernyataan diatas didukung dengan penelitian yang dilakukan oleh Mudgal dan Tiwari (2015) yang melakukan perbandingan forgiveness dan kepuasan hidup individu yang mengalami HIV/AIDS dengan individu normal, hasilnya menunjukkan bahwa individu dengan HIV/AIDS memiliki tingkat forgiveness dan kepuasan hidup yang rendah. Mudgal dan Tiwari (2015) menjelaskan bahwa individu yang terinfeksi HIV/AIDS tentunya memiliki situasi yang kompleks dibandingkan orang normal. Selain tekanan sosial, pengobatan rutin yang wajib dilakukan, dan biaya berobat juga memengaruhi individu dalam memaknai kepuasan hidup mereka (Zulman et al., 2013). 
Penelitian yang dilakukan oleh Mudgal dan Tiwari (2015) mengenai kepuasan hidup dan forgiveness pada individu dengan HIV menunjukkan hasil bahwa jenis kelamin merupakan salah satu faktor yang mempengaruhi kepuasan hidup seseorang. Penelitian ini ingin mengkaji lebih lanjut apakah ada perbedaan kepuasan hidup jika ditinjau dari jenis kelamin.

Berdasarkan fenomena yang telah dijelaskan di atas, maka peneliti merumuskan masalah pada penelitian ini yaitu apakah terdapat perbedaan kepuasan hidup pada perempuan dan pria yang terinfeksi HIV/AIDS.

\section{METODE PENELITIAN}

\section{Partisipan dan Prosedur Penelitian}

Partisipan pada penelitian ini adalah individu yang terinfeksi HIV/AIDS di komunitas " $Z$ " dengan jumlah partisipan perempuan sebanyak 36 orang dan partisipan pria sebanyak 30 orang. Pengambilan data dilakukan dengan menggunakan metode purposive sampling dengan rentan waktu pengambilan data selama satu bulan. Pada penelitian ini data diperoleh melalui kuesioner penelitian dan prosedur wawancara.

\section{Instrumen Penelitian}

Penelitian ini menggunakan alat ukur Satisfaction with Life Scale (SWLS) yang telah di terjemahkan dalam bahasa Indonesia (Tobing, 2009). Satisfaction with Life Scale terdiri atas 5 butir pernyataan. Setiap butir pernyataan memiliki 7 pilihan jawaban yang dapat pilih. Nilai skor setiap butir dimulai dari skor 0 hingga 7. Kategori skor pada skala ini dimulai dari 0-7 dengan kategori extremely dissatisfied, 10-14 dengan kategori dissatisfied, 15-19 dengan kategori slightly dissatisfied, 20 dengan kategori netral, 21-25 dengan kategori slightly satisfied, 26-30 dengan kategori satisfied, dan 31-35 dengan kategori extremely satisfied (Diener, Emmons, Larsen, \& Griffin, 1985).

\section{Teknik Pengolahan Data}

Pada penelitian ini teknik pengolahan data statistik yang digunakan adalah SPSS 17 dengan menggunakan uji reabilitas dan validitas, uji normalitas, dan uji beda (independent sample t-test). Berdasarkan hasil uji validitas dan reabilitas, diperoleh data bahwa semua butir pada alat ukur Satisfaction with Life Scale (SWLS) dinyatakan valid dan reliabel. Uji normalitas yang dilakukan juga menunjukkan bahwa data berdistribusi normal

\section{HASIL DAN PEMBAHASAN}

Pada penelitian ini didapatkan data sebanyak 66 orang dengan pembagian data laki-laki sebanyak 30 orang dan perempuan sebanyak 36 orang. Hasil uji beda independent sample t-test menunjukkan nilai rata-rata ODHA laki-laki sebesar 25.63 dan ODHA perempuan memiliki nilai rata-rata sebesar 23.41. Nilai signifikansi menunjukkan hasil $p=0,243(0,243>0,05)$. Nilai signifikansi lebih dari 0.05 $(p>0.05)$, menunjukkan bahwa tidak terdapat perbedaan signifikan antara odha laki-laki dan perempuan. Hasil uji beda dapat dilihat pada tabel 1. Hasil uji beda menunjukkan bahwa tidak ada perbedaan kepuasan hidup antara perempuan dan laki-laki dengan HIV/AIDS. Hasil uji beda dapat dipengaruhi oleh beberapa faktor yaitu jumlah sample ODHA laki-laki yang lebih sedikit dibandingkan ODHA wanita dan keterbatasan jumlah sample penelitian. Berdasarkan kepuasan hidup pada ODHA laki-laki ditemukan 1 orang memiliki tingkat kepuasan hidup pada kategori dissatisfied, 4 orang slightly dissatisfied, 3 orang neutral, 6 orang slightly satisfied, dan 8 orang dalam kategori extremely satisfied. Pada ODHA perempuan sebanyak 3 orang masuk dalam kategori extremely dissatisfied, 2 orang dissatisfied, 7 orang termasuk kategori slightly dissatisfied, 2 orang neutral, 4 orang slightly satisfied, 9 orang satisfied, dan 8 orang extremely satisfied. 
Berdasarkan hasil pengolahan data yang dilakukan peneliti terhadap 30 odha perempuan dan 36 odha laki-laki menunjukkan tidak ada perbedaan nilai kepuasan hidup laki-laki dan perempuan dengan HIV/AIDS. Nilai rata-rata kepuasan hidup odha laki-laki lebih tinggi yaitu 25.6 dan odha perempuan sebesar 23.4. Hasil signifikansi pada penelitian ini sebesar $2.43>0.05$ yang berarti tidak ada perbedaan yang signifikan kepuasan hidup pada odha laki-laki dan perempuan, hal ini dikarenakan keterbatasan sampel pada penelitian ini sehingga memengaruhi nilai signifikansinya. Tidak adanya perbedaan kepuasan hidup antara odha laki-laki dan perempuan juga dapat dipengaruhi oleh terpenuhinya domain satisfaction pada keduanya.

Hasil pengolahan data yang telah peneliti lakukan menunjukkan bahwa nilai rata-rata kepuasan hidup odha perempuan lebih rendah dibandingkan odha laki-laki. Hal ini dapat disebabkan karena sample odha perempuan pada penelitian ini merupakan odha yang terinfeksi dari suaminya. Sesuai dengan pernyataan Riasnugrahaini (2011) yang menyatakan bahwa perempuan yang tertular HIV melalui suaminya cenderung mengalami tekanan yang lebih berat dalam menghadapi keadaannya. Hal ini dikarenakan ia tidak melakukan perilaku berisiko namun harus mengalami dampak positif HIV.

Wawancara yang dilakukan peneliti pada odha perempuan, diperoleh data bahwa odha perempuan selain harus menanggung beban ekonomi karena suaminya yang meninggal karena HIV, mereka juga harus berjuang untuk membesarkan anaknya. Odha perempuan yang peneliti temui umumnya belum open status karena takut akan mendapat stigma negatif dari masyarakat. Pada odha laki-laki nilai kepuasan hidup dapat lebih tinggi dikarenakan selain memiliki kelompok dukungan sebaya. odha laki-laki juga lebih berani untuk open status mereka pada keluarga inti mereka serta beberapa dari odha laki-laki sudah pernah mengalami fase kritis yang disebabkan oleh infeksi oportunis yang menyebabkan mereka tidak sadarkan diri dan membuat keluarga mereka cemas. Faktor tersebut akhirnya memberikan dorongan intrisik dalam diri odha laki-laki untuk mulai menerima kondisi mereka sehingga hal ini berdampak pada penilaian mereka terhadap kepuasan hidupnya.

Hasil penelitian di atas sesuai dengan penenelitian yang dilakukan oleh Strine, Chapman, Balluz, Moriarty, dan Mokdad (2008) bahwa faktor-faktor yang berhubungan dengan kesehatan seperti penyakit kronis, kegelisahan, dan gangguan fungsi fisik berkorelasi positif dengan kepuasan hidup seseorang. Hasil pada penelitian ini sesuai dengan penelitian sebelumnya yang dilakukan oleh Vicki, Rose Anne dan Francesca (2012) yang menyatakan bahwa infeksi HIV/AIDS akan menimbulkan munculnya infeksi oportunis bagi odha, sehingga akan memengaruhi aspek-aspek kehidupan odha lainnya dan menimbulkan munculnya permasalahan psikologi, munculnya kecemasan, ketakutan, dan menurunya kepuasan hidupnya. Hasil penelitian yang menunjukkan tidak adanya perbedaan kepuasan hidup yang signifikan antara odha laki-laki dan perempuan juga dapat disebabkan karena pengaruh dari terbentuknya kelompok dukungan sebaya. Pernyataan ini sesuai dengan hasil penelitian Hidayah (2014) yang menunjukkan bahwa dukungan sebaya dapat meningkatkan kesejahteran psikologis odha yang akan mempengaruhi penilaian odha terhadap tingkat kepuasan hidupnya. 
Tabel 1. Independent sample test

\begin{tabular}{|c|c|c|c|c|c|c|c|c|}
\hline & \multicolumn{7}{|c|}{ Hasil Uji Beda Kepuasan Hidup } \\
\hline & & \multirow[b]{2}{*}{$\mathrm{N}$} & \multirow[b]{2}{*}{ df } & \multirow[b]{2}{*}{$\begin{array}{c}\text { Sig. } \\
\text { (2-tailed) }\end{array}$} & \multirow[b]{2}{*}{ Mean } & \multirow[b]{2}{*}{$\begin{array}{c}\text { Std } \\
\text { Deviation }\end{array}$} & \multicolumn{2}{|c|}{$\begin{array}{l}\text { 95\% Confidence Interval } \\
\text { of the Difference }\end{array}$} \\
\hline & & & & & & & Minimum & Maximum \\
\hline \multirow[t]{2}{*}{ TOTAL } & $\begin{array}{l}\text { Odha } \\
\text { Laki-laki }\end{array}$ & 30 & 64 & .243 & 25.6 & 0.34 & 1.4 & 4.1 \\
\hline & $\begin{array}{l}\text { Odha } \\
\text { Perempuan }\end{array}$ & 36 & 62.697 & .229 & 23.4 & 0.51 & 1.3 & 3.6 \\
\hline
\end{tabular}

\section{KESIMPULAN DAN SARAN}

Hasil penelitian ini menunjukkan tidak adanya perbedaan kepuasan hidup yang signifikan antara odha laki-laki dan perempuan. Faktor jenis kelamin tidak mempengaruhi kepuasan hidup pada odha. Tidak adanya perbedaan kepuasaan hidup ini, juga dapat disebabkan karena pengaruh dari terbentuknya kelompok dukungan sebaya. Adanya kelompok dukungan sebaya memberikan wadah bagi odha untuk dapat memberikan dukungan satu sama lain sehingga mempengaruhi penilaian mereka terhadap kepuasan hidup.

Saran bagi penelitian selanjutnya yang ingin mengangkat topik kepuasan hidup pada odha agar mengambil jumlah sampel yang lebih banyak dan dilakukan analisis lebih mendalam dengan melihat indikator lain yang dapat mempengaruhi kepuasan hidup odha. Penelitian selanjutnya juga diharapkan tidak hanya berfokus untuk mengumpulkan data-data tetapi juga melakukan intervensi psikologi yang membantu untuk meningkatkan kepuasan hidup maupun aspek psikologis lain pada odha. Penelitian ini diharapkan menjadi data tambahan yang dapat membantu intitusi baik yayasan, rumah sakit, maupun lembaga swadaya masyarakat dalam menangani individu dengan HIV/AIDS.

\section{Ucapan Terima Kasih}

Penulis mengucapkan terima kasih kepada YPI yang telah memberikan izin pengambilan data. Penulis juga mengucapkan terima kasih kepada semua narasumber yang telah berpartisipasi di dalam penelitian ini.

\section{REFERENSI}

Departemen Kesehatan RI [Depkes RI]. (2017). Situasi HIV/AIDS di Indonesia tahun 2011-2016. Jakarta: Pusat Data dan Informasi Departemen Kesehatan RI.

Diener, E. (2009). Subjective well-being. Dalam Diener, E. (Ed.). The science of well-being: The collected works of Ed Diener series 38 (hal. 27-34). Champaign: Springer.

Diener, E., Diener, M., \& Diener, C. (2009). Factors predicting the subjective wellbeing of nations. Social Indicators Research Series, 38, 43-70. doi:10.1007/978-90-481-2352-0_3

Hidayah, N. (2014). Efektivitas group positive psychotherapy untuk meningkatkan kesejahteraan psikologis pada orang dengan hiv/aids (odha). Unpublished thesis; Surakarta: Universitas Muhammadiyah.

Katz, I. T., Ryu, A. E., Onuegbu, A. G., Psaros, C., Weiser, S. D., Bangsberg, D. R., \& Tsai, A. C. (2013). Impact of hiv-related stigma on treatment adherence: Systematic review and meta-synthesis. Journal of International AIDS Society, 16(2), 1-25. Retrieved from https://onlinelibrary.wiley.com/doi/abs/10.7448/IAS.16.3.18640

Moskowitz., Wrubel,. Hult,. Maurer,. \& Acree., (2013). IIlness Appraisals and depression in the first year after hiv diagnosis. PLoS ONE, 8(10), Article e78904. https://doi.org/10.1371/journal.pone.0078904

Mudgal, S., Tiwari, G, K. (2015). Self-Forgiveness and Kepuasan hidup in People Living with HIV/AIDS. The International Journal of Indian Psychology. doi: 10.25215/0301.176 
Riasnugrahani, M. (2011). Studi kasus mengenai forgiveness pada wanita dengan HIV/AIDS yang terinfeksi melalui suaminya: Analisis mengenai kaitan forgiveness dengan tingkat kesehatan ODHA, dalam Prosiding Konferensi Nasional "Pain Management \& Quality of Life" Fakultas Psikologi Universitas YARSI, 5, 180-190.

Sarafino, E. P., \& Smith, T.W. (2010). Health Psychology: Biopsychosocial Interactions (7 $^{\text {th }}$ ed.). New York: John Wiley \& Sons, Inc.

Schweitzer, A., Mizwa, M. B., \& Ross, M. W. (2010). Psychosocial aspects of hiv/aids: Adults. In Baylor International Pediatric AIDS Initiative, HIV curriculum for the health professional (pp. 334-349). Texas, USA: Baylor College Medicine.

Siahaan, M. (2017). Dampak stigma negatif dan diskriminasi masyarakat terhadap orang dengan hiv/aids (ODHA) di Medan Plus, Tanjung Sari, Medan (Skripsi). http://repository.usu.ac.id/bitstream/handle/123456789/66392/Chapter\%20IIIVI.pdf? sequence $=2 \&$ is Allowed $=\mathrm{y}$

Strine, T. W., Chapman, D. P., Balluz, L. S., Moriarty, D. G., \& Mokdad, A. H. (2008). The associations between kepuasan hidup and health-related quality of life, chronic illness, and health behaviors among U.S. community-dwelling adults. Journal of Community Health, 33, 40-50. doi:10.1007/s10900-007-9066-4

Tobing, L.S.P. (2009). Adaptasi budaya pada alat ukur subjective happiness scale, satisfaction with life scale, dan schedule for evaluation of individual quality of life direct weighing. Unpublished thesis, Depok: Universitas Indonesia.

Vicki, E. Hutton. Rose Anne, M. \& Francesca, E.C. (2012). Subjective wellbeing and 'felt' stigma when living with HIV. Qual Life Res 22:65 - 73. doi: 10.1007/s11136-012-0125-7

World Health Organization. (2017). World Health Statistics; UNAIDS. Global Report: UNAIDS report on the global AIDS epidemic 2017. Geneva: Joint United Nations Programme on HIV/AIDS; 2017.

Zulman, D. M., Asch, S. M., Martins, S. B., Kerr, E. A., Hoffman, B. B., Goldstein, M. K. (2013). Quality of care for patients with multiple chronic conditions: the role of comorbidity interrelatedness. Journal of General Internal Medicine, 29 (3)529-537. 